\title{
Small Business Start-up and Future Option: An Example of Food Restaurant Formation in South-East Cape-Town, South Africa.
}

\author{
Anyesha Amos Audu, Maku Sampson Hassan Rakiya Altine Umar. \\ School of Basic and Remedial Studies, Department of Social Sciences, \\ Business Management Unit, Nasarawa State Polytechnic, P M B 109, Lafia-Nigeria.
}

\begin{abstract}
Our entrepreneurship food venture in Cape-Town satisfied the dire needs of customers in the environment. It's obvious that innovations endows resources and creates wealth and adds value to the development of business. However, business flourished in South Africa own to the fact that the city has economic growth especially in small business as this restaurant business development improved. More so, our exemplary business adopted a competitive strategy to enhanced market shares, sales volume increase, price cuts and promotional strategies of quick delivery and quality food and customers value. While, the objective is to a achieve holistic integration of both internal variables such as inimitable skills and business capabilities, value and organisational distinct assets by a frame work structure of an ansoff matrix analysis
\end{abstract}

Keywords: Entrepreneurship, business development, competitive strategy and ansoff matrix analysis.

\section{Introduction}

A food restaurant is established to satisfy the dire urge of the city-consumers, travellers, adventurers and tourist voyage in the famous South-east of Cape-Town. The restaurant name "South-east food restaurant" is synonymous to the long traditional historical settlement of the whites in the seaports area focal point for shipping from Atlantic with a busy walkway in the world from Dubai and real lines to other parts of the World (Welvaart, 2006). While Cape-Town has been widely known for its economics activities (exports and imports) with the U.K, Mozambique, Belgium, U.S and other parts of the World. More so, the city has attractive sporting activities that draw people from the work of life and tourist activities such as, river rafting, fishing, mountain biking, rock climbing etcetera, however, with the teaming population of Cape-Town and the individual experiences and will for self employment opportunities, prompt our desire to filled this pressing consumers support and needs (Morkel, 2001) according to (Drucker, 2011) innovation endows resources and creates with wealth capacity to adding value. The exploitation of new idea of ours becomes necessary which result to new products, process and services (Shukla, 2009).

However, our vision was made manifest due to the fact that the city has economic opportunities and potentials in commerce and economic growth in small businesses coupon and supporting program for such business formation (Hammond, 2012).

\section{Study "Story".}

\section{Research and evidence of business formation in Cape-Town}

Various authors' and scholars written and analyse business Market Growth and expansion over the years. The assessment of present and identification of untapped markets and seeking opportunities for revenue, growth either by a new market opportunity or expansion of the existing one. Market expansion and growth is to explore strategy in delivery of new capabilities, traits to current market potentials and for existing products in a geographical region or within (Bennet, 1998). While, the outlook of our sales for the year and future option plan and ahead depends on the growth and development of Cape-Town city and most importantly the competitive business strategy we emphasised, based on information gathered and analysis in relation to the business segment plan to serve and based on the competitive appeals channels such as distinct promotion, distribution, promotion and pricing (Brown, Barrow and Barrow, 2008). While, it could be agreed that Leadership and Entrepreneurial traits are important in future achievement by each partners displaying sense of inimitable, commitment and hard work. To achieve more the needs for intense mission of achievement, vision to for fill and dire a progressive goal of business success (Javitch, 2009). For, in a collective term as hard work, determination skills and abilities to demonstrate total mastery of every requisite in our business in other to bridge the previous inefficiencies (if any). On the other hand communication and interpersonal skills that delineates business staff and customers in most organisations are relevant issues to uplift business, which our inclusive channel of success. It's obvious that a doubtful and vague entrepreneurial credibility is loopholes of failures, undetermined, ill motivation are pessimistic tendencies which serve as challenges for businesses failures. On the other hand, it is believed that Market competitors and strategy are means used by rivals in the same mode of business to thwart down firms performance and profits, others includes market shares, sales volume by varying their strategic marketing mix of 
price cuts, products initiative, imitation and promotional strategies (Bennett, 1998). While, issues such as sales revenue which is revenue less cost to achieve profits or loss. Business survival and development, depends mostly on viable sales based on understanding the market and delivery quality, value to customers as a reason for their purchases and continue patronage to the products and services returning revenue to the business are indices which grow business now and future (Michael, 2004). Innovation challenges are issues bothering business growth and new products depends on existing organisational strength and capabilities which prompted through flexible opportunities and initiatives (Beaver, 2002).

However, sustainable "innovation" is the core to sustain human society through business performances growth and development. Business success is in creating sustainable products toward business continuity for future development and not relied on statuesque, adding together value through inimitable strategies. While indeed Innovation breeds sustainability with excellent and systematic sources of inspiration and growth for our food restaurant in Cape-Town South Africa (Gobble and Anne, 2012).

Furthermore, business time and effective operational management are well design schedule to provide accurate insight with better enabling focus for a business to adopt new changes in both within and out of the business environment. While for a business to succeed even to future, the decision is to use current data and information to extract better business policies and analysis to achieve competitive advantages (Bell, etal, 2010). In achieving business objective, there should be Integration of internal variables such as skills and capabilities, business values, and the organisational distinct assets. However, the external data integrate across suppliers, customers and intending entrants including current competitors to make strategic business decisions for business successfulness in the present and future result (option).

\subsection{Theoretical Frame Work.}

\section{Business development: "'an enterprise."}

The features of an entrepreneurial enterprise have been personality and independence (Nooteboom, 1994) high percentage of small scale enterprise distributed in various markets reflects the important characteristics of small business its diversity, which are the goal of entrepreneurs. Over time, the relevancy of entrepreneurial growth and factors it's contributed to humanity are enormous (economic development). Business growth and development are the outcome of strategic choices of entrepreneurs and the structural characteristics of the external working environment (Eisenhardt and Schoonhoven, 1990). (Storey, 2000) noted that for much business owners the growth of their business is not an objective, but survival (Morrison, Breen and Ali, 2003) business opportunities and advantages are information and knowledge possess by the entrepreneurs' (enterprise) (Shane, 2000). Prior knowledge feed positive opportunity and recognition, values, belief and goals has effects on which opportunities the entrepreneur will select for his strategic decision. A focus and directional enterprise easily achieve gaols, especially with high possession of unique traits skills, capability, knowledge and proprietary expertise (Maes, etal, 2004). Firms functioning knowledge is implicit and related to its craftsmanship. (Nooteboom, 1994). Small scale enterprise has a limited capacity for marketing strategy acquisition of new knowledge and technology and very sensitive to external pressure and risk (Martinsuo and Kullberg, 1998) Though, its linked to flexibility, pure organisation, centralised decisions-making and closeintimate to customers (Julien, 1993, Storey, 2000) less formalities in both external and internal information and communication systems, which allow shorter interior lines of communication, fast responses, time and speedy solution solving most often.

\subsection{The Sales Forecasting.}

The essential parts of business planning is sales forecasting which guide against business uncertainty and prevent overstocking and over-investment, it write down business value, its products and sales and it is precise to achieve expected sales (Gleeson, 2009) Sales forecasting, budgeting and business planning are indispensable to the survival and continuing success of a business, regardless of the business volume and the level of uncertainty. Forecasting are useful way for inform decisions making on sales with high degree of probability and a likely strong effect on demand and the variety of persuasive outcomes with an imagined sequence of possible events, considered, discussed and then assigned probabilities.

Sale forecast attempt to find solution to the business planning process by ascertaining number of stocks to hold, percentages of staff to employ, materials to buy, sales figure to predicts, the cash-flow forecast and the funding requirement for the business. Business valuing depends on projection of revenue ahead, sales and will determine the acceptance by bank to lend and convince investors to invest and direction on how much a business investors expect in exchange for funding. Sales forecast is to interpret concretes business idea into business plan in other to match the targeted-margin especial on a future period (Brown, Barrow and Barrow, 2008). 


\subsection{Business Development: ''an enterprise.' Future option:}

It is obvious that many writers attempt to differentiate between entrepreneur and enterprise. The former founds an enterprise in pursuit of profit and growth and further engages in innovative and initiatives behaviours in practice of strategic management to achieve these objectives. While the letter, could manifestly pursue business objective personal objectives, such as independence, control and growth (Beaver, 2002).

Furthermore, an entrepreneurial enterprise personality and independence. (Nooteboom, 1994) posits that high percentage of small scale enterprise distributed in various markets reflects the important characteristics of small business its diversity, which are the goal of entrepreneurs. In recent times and years the relevancy of entrepreneurial growth and factor s it's contributed to humanity and society are enormous (economic development). Business growth and development are the outcome of strategic choices of entrepreneurs and the structural characteristics of the external working environment (Eisenhardt and Schoonhoven, 1990). (Storey, 2000) noted that for much business owners the growth of their business is not an objective, but survival (Morrison, Breen and Ali,2003) summarily distinguish features of pro-growth small business is a balance arrangement of the owner-managers objective, the business abilities, capabilities an environment opportunity. Business opportunities and advantages are information and knowledge possess by the entrepreneurs' (enterprise) (Shane, 2000) prior knowledge feeds positive opportunity and recognition, values, belief and goals has effects on which opportunities the entrepreneur will select for his strategic decision. A focus and directional enterprise easily achieve gaols, especially with high possession of inimitable traits skills, capabilities, knowledge and proprietary expertise (Maes, etal, 2004) (Nooteboom, 1994) recognised that small scale business operating knowledge is understood and related to craftsmanship.

According (Martinsuo and Kullberg, 1998) small scale enterprise has a limited capacity for marketing strategy acquisition of new knowledge and technology and very sensitive to external pressure and risk. Though, its linked to flexibility, organic organisation, centralised decisions-making and close-intimate to customers (Julien, 1993 , Storey, 2000) less formalities in both external and internal information and communication systems, which allow shorter internal lines of communication, fast responses, time and speedy solution solving most often.

\subsection{Better Sales Forecasting and Demand Planning.}

Sales forecasting and demand planning are process which business increases forecasting accuracy, speed planning cycles, reduce inventory costs, end stock out and increase customer's satisfaction continually. This is done through viable strategy of employees-customers ties, innovative, data range, accurate and tactical forecast (Kugel, 2008).

However, sales forecasting has a distinct approaches and can be carried out distinctly in other to forecast accurately in the next couple of years. Sale are broken down into manageable units by sales assumption by line of projected sales and revenue based on sale basis and the result of the standard sales are computed based on projected sales and cost and quantity (Barry, 2000) and revenue derived are returns to the business. Forecast is mostly based on historical sales data, analysis of market study, trends as basis to targeted sales. While budget are based on accurate and timely business plan as a means of achieving a competitive advantage (Ranck, 1986). Success of business depends on sales forecast and all aspects of business operations is relied on forecast (Mentzer, 1999) the importance of sales forecast are much, the most method use are either based on descriptive and simple consensus approach with past experiences and previous sales data of years, as found in the study (Snyder,1993, Meyer, 1992), showed that years planning and decisions have been based solely on potential estimates that usually are inaccurate by either over estimating market potentials and market shares ( Cranage, 2003).

\subsection{Ansoff Matrix Analysis.}

The structure and the strategies of growth shall be related to Ansoff matrix (Ansoff, 1965) market penetration strategies, market development analysis, and products development growth and diversification series.

\subsection{Market penetration strategies:}

This attracts customers through competing on products and service without moving outside the organisation present scope but continue with active customers in the market by selling more to existing customers (Ansoff, 1965).But greedily, a challenge customer on products or services are not directly attack, this if done without caution, can reduce business profit margin. Though, it's cheaper in retaining existing customers on consumers' goods. ' 'market penetration in existing market" is effective and result oriented only if improvement in quality of products and services is achieve, mostly embarking on intense promotional appeal strategies increase market share are among our business strategy (Lynch, 2009). 


\subsection{Product Development Growth:}

Business formation and sustenance necessitate the enormous value of positive customer relationship and goodwill trust that flows within it. Developing new products/services for existing market or adopting new product/services for new market. Business sometimes re-modifies, improve, brand and extend to strategic means of appealing to customers. However, this business focus beyond its existing customer's niche by attracting and drawing new customers into the services loyalties of the food restaurant and the market penetration within the existing customers groups our effort to prolong the life cycle of our business now and into the future (Martin and Thompson, 2010).

\subsection{Market Development Analysis:}

The value of products and life cycle are extended into a new market to enlarge its life span, with improvement, and allow growing in a new market. It's low risk strategy with development and growth strategies of adding value, repackaging, promotion, new segment market and selling same products/services in an improved new market (Lynch, 2006). The assessment of present and identification of untapped markets and seeking opportunities for revenue, growth either by a new market opportunity. Market development; explore strategy in delivery of new capabilities, to current market potentials and for existing products in a geographical region or within as in the case of this south-east Cape-Town (Bennet, 1998). The outlook of our sales for future year's option will adopt the market penetration strategy of selling more to existing and to improve existing customer by selling more. Our business opportunities is to sale and generate more revenue, improve products/services and strategic planning on market growth and development. Competitive advantages are strategies based on information gathered and analyse in relation to business segment and plan toward competitive appeals as promotion, distribution, and price, while still sustaining the business with high anticipated profit (Brown, Barrow and Barrow, 2008).

\subsection{Diversification Series.}

An attempt to invest and most challenging, costly and risky of the options, new skills and relationship need to be developed. Though, risky but can form business synergy of two to generate more profit and burst strategies. While, our business has not yet thought of this option.

\section{Methodology: Analysis- application of theory to evidence}

Pursuing new Market opportunity Networking.

Business development is the creation of long-term value for organisation from customers, market and relationship in figuring out how the interactions of forces combine to create opportunity for growth. This "longterm value" are cash and it is the life blood of a business, prestige, strategy seek by firm to grow (Pollack, 2012) it's also the intensified and calculative efforts to increase our business strategies in achieving more markets shares and relationship with the environment context, forging forward and exploring opportunities toward goal attainment according to plan (Beaver, 2002). To increase output and more patronage of our food services in the environment and beyond we hire a marketing expert, who is enthusiastic, detail oriented and self motivated toward customers attainment he is on field work to identifying sensitize on creating more awareness to potential customers, with circulation of handbill in city with the aids of at least two daily paid hire workers, with an optimism that an increase level of market share and expansion shall be attained (Bennett, 1998 ).

\section{Conclusion}

Our Customers Relationship Management is plan toward better level attainment over the previous year, with better interactions, current and future customers target with improve customer's satisfaction and maximise higher profit subsequently.

\section{References}

[1]. Asoff, H.I., 1965. An Analytical Approach to Business Policy for Growth and Expansion. McGraw-Hill New York: Edited 2002. [2]. Barry, T., 2000. A Simple Approach to Sales Forecasting,[online] Available at: $<$ http://www.inc.com/articles/2000/03/17871.html $>$ [Accessed $9^{\text {th }}$ February 2013].

[3]. Brown, R., Barrow, P., and Barrow, C., 2008. The Business Plan Workbook, $6^{\text {th }}$ ed. Kogan page: London and Philadelphia.

[4]. Beaver, G.,2002, Small Business Entrepreneurships and Enterprise Development, Pearson Education Limited.

[5]. Bennett, R., 1998. Small Business Survival, Pearson Education Limited.

[6]. Brown, R., Barrow,P., and Barrow, C.,2008. The Business Plan Workbook, $6^{\text {th }}$ edition Kogan page London and Philadelphia

[7]. Bell, etal, 2010. When and how to innovate your Business Model,[online] Available at: Anglia Ruskin University< $<$ http://www.emeraldinsight.com/learning/management thinking/articles/innovate bm.htm $>$ [Accessed 19th February 2013]. V

[8]. Cranage, D., 2003. Practical time Series Forecasting for Hospitality Manager, Available through: Anglia Ruskin University library website $<$ http://www.emeraldinsight.com/journals.htm?issn=09596119 \&volume $=15$ \&issue $=2$ \&articleid $=867462 \&$ show $=$ html $>\left[\right.$ Accessed $10^{\text {th }}$ February 2013 ]

[9]. Drucker, F. P., 2011.Innovation and Entrepreneurship Practice and Principles.Revised Edition Routledge London and New York. 
Small Business Start-up and Future Option: An Example of Food Restaurant Formation in South....

[10]. Eisenhardt, K.,M.,and Schoonhoven, C., B.,1990.” Organisational Growth: Linking Team, Strategy environment and U.S Semi Conductor Ventures 1978-1988 admin sc quarterly V35 N3.P504-529.[online] Available at:< http://connection.ebscohost.com/c/articles/9102111389/organizational-growth-linking-founding-team-strategy-environmentgrowth-mong-u-s-semiconductor-ventures-1978-1988 [Accessed $10^{\text {th }}$ February 2013].

[11]. Gobble, M., and Anne,M.,2012 . Innovation and Sustainability, [online] Available at: Anglia Ruskin University, $<$ http://go.galegroup.com/ps/retrieve.do?sgHitCountType=None\&sort=DA-

SORT\&inPS=true\&prodId=AONE\&userGroupName=anglia itw\&tabID=T002\&searchId=R1\&resultListType=RESULT LIST\&c ontentSegment=\&searchType=BasicSearchForm\&currentPosition=11\&contentSet=GALE|A302110443\&\&docId=GALE|A302110 443\&docType $=$ GALE\&role $>\left[\right.$ Accessed $10^{\text {th }}$ February 2013].

[12]. Hommand, E., 12012 http://www.informationweek.com/software/business-intelligence/six-steps-to-better-sales-forecastingan/209000118> [Accessed 12 $2^{\text {th }}$ March 2013].

[13]. Javitch,G.,D.,2009. Characteristics of Superior Leaders $<$ http://www.entrepreneur.com/article/204248 $>$ [Accessed $12^{\text {th }}$ March 2013].

[14]. Julien, P., A., 1993.Small Business as research subject. Some Reflections on Knowledge of Small Businesses and its effects on economic theory " small business economics vol.5 no. 2 pp 157-66.[online] Available at: Anglia Ruskin University: $<$ http://www.garfield.library.upenn.edu/histcomp/mansfield-e citing/node/2356.html $>$ [Accessed $11^{\text {th }}$ February 2013].

[15]. Kugel, D.R., 2008. Six Steps to Better Sale forecasting and Demand Planning,[online]Available at: $<$ http://www.informationweek.co.uk/software/business-intelligence/six-steps-to-better-sales-forecastingan/209000118 $>$ [Accessed $12^{\text {th }}$ March 2013].

[16]. Kugel, D., R.,2008. Six Step to Better Sale forecasting and Demand Planning

[17]. https://www.capetown.gov.za/en/investing/Pages/default.aspx $>$ [Accessed $12^{\text {th }}$ March 2013].

[18]. Lynch, R., 2006. Strategic Management, Pearson Education Limited $4^{\text {th }}$ Edition, Available through: Anglia Ruskin Website $<$ http://lib.myilibrary.com/Open.aspx?id $=60202 \&$ src $=0>$ [Accessed 15 th February 2013].

[19]. Lynch, R., 2009. Strategic Management, $5^{\text {th }}$ Edition: Pearson Education Limited.

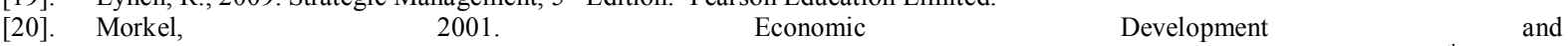
Tourism. $<$ http://info.worldbank.org/etools/docs/library/166856/UCMP/UCMP/Documents/capetown.pdf $>$ [Accessed $12^{\text {th }} \quad$ March 2013].

[21]. Mentzer, J.,1991 "Bench marking Sales Forecasting Management," [online]Available at: $<$ http://www.emeraldinsight.com/search.htm?st1 =Benchmarking+sales+forecasting + management $\% 22 \% 2 \mathrm{C}+$ Business + Horizons \&ct $=$ all\&ec $=1 \& b f=1 \&$ sr1 $=$ Benchmarking\%20sales\%20 forecasting\%20ma Michael, $\quad$ N., K.,2004.Return on Investment Selling,[online] Available at: Anglia Ruskin University[online]Availableat: $<$

[22]. http://site.ebrary.com/lib/anglia/docDetail.action?docID $=10064739>$ [Accessed $9^{\text {th }}$ February, 2013].

[23]. Meyer, F.,1992. Building Product Forecasting Journal of business forecasting,[online] Available at: ARU VOL 10 N0.4 P23-4 http://scholar.google.co.uk/scholar? q $=\% 22$ Building+product + forecasting $\% 22,+$ Journal + of + Business + Forecasting, \&hl=en\&as sdt= 0 \&as vis $=1 \&$ oi $=$ scholart\&sa $=$ X\&ei $=$ sgXUfzSEOad0AWQsICgCw\&ved $=0$ CEIQgQMwAA $>$ [Accessed $9^{\text {th }}$ February, 2013].

[24]. Mentzer, J.,1991) "Bench marking Sales Forecasting Management" Business Horizons v 43.n3 p4856[online]Availableat: $<$ http://www.emeraldinsight.com/search.htm? st $1=$ Benchmarking + sales + forecasting + management $\% 22 \% 2 \mathrm{C}+$ Business + Horizons \&ct=all\&ec $=1 \& \mathrm{bf}=1 \& \mathrm{sr} 1=$ Benchmarking $\% 20$ sales $\% 20$ forecasting $\% 20$ management $\% 22, \% 20 \mathrm{Business} \% 20 \mathrm{Hori}$

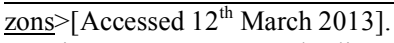

[25]. Morrison,A., Breen,J., and Ali. S.,2003. Small Business Growth Intention, Ability and Opportunity, 'Journal of Small Business $\begin{array}{lllll}\text { Management, } & \text { Vol41 } & \text { No.4 } 417-425 \text {.[online]Available anglia } & \text { Ruskin }\end{array}$ University: $<$ http://onlinelibrary.wiley.com/doi/10.1111/1540-627X.00092/abstract $>$ [Accessed 11th February 2013].

[26]. Maes, etal, 2004. "'Learning about Small business Profitability: The influence of Management Practices and owner -Managers human Capital'. Vlerick Leuven, Gent, Working paper Series 2004/07, [online]Available at: Anglia Ruskin University: https://lirias.kuleuven.be/bitstream/123456789/85371/1/vlgms-wp-2004-07.pdf [Accessed 11th February 2013].

[27]. Martinsuo and Karlberg, 1998. "' Motives for Studing Small and Medium-Size firms"' in Montisuo, jarvenpaa(Eds), Development and Challenges of Small and Medium-size Enterprise, HUT industrial Management and working organisational psychology, Espoo, working papers 13, pp.3-10.[online] Available at: Anglia Ruskin University $<$ http://www.google.co.uk/search? $=$ =Martinsuo\%2C+M. $\% 2 \mathrm{C}+$ Karlberg\%2C+A.+\%281998\%29\%2C+\%22Motives+for + studying + small + and + medium-

sized + firms $\% 22 \% 2 \mathrm{C}+\mathrm{in}+$ Martinsuo $\% 2 \mathrm{C}+\mathrm{J} \% \mathrm{C} 3 \% \mathrm{~A} 4 \mathrm{rvenp} \% \mathrm{C} 3 \% \mathrm{~A} 4 \% \mathrm{C} 3 \% \mathrm{~A} 4+\% 28 \mathrm{Eds} \% 29 \% 2 \mathrm{CDevelopment}+$ and + Challenges + of + Small+and+Medium-

Sized+Enterprises $\% 2 \mathrm{C}+\mathrm{HUT}+$ Industrial + Management + and + Working + Organizational+Psychology $\% 2 \mathrm{C}+$ Espoo $\% 2 \mathrm{C}+$ Working $+\mathrm{Pa}$ pers $+13 \% 2 \mathrm{C}+$ pp.3-10.\&ie $=$ utf- $8 \&$ oe $=$ utf- $8 \&$ aq $=$ t\&rls $=$ org.mozilla:en-US:official\&client=firefox-a $>$ [Accessed 11 th February 2013].

[28]. Nooteboom, B., 1994. Innovation and Diffusion in Theory and Evidence: VOL 6 Iss 5 p327-347[online] Available at:< http://link.springer.com/article/10.1007\%2FBF01065137?.LI=true $>$ [Accessed 11th February 2013].

[29]. ${ }_{2}$ Pollack, S. 2012. What exactly is business development? $<$ http://www.forbes.com/sites/scottpollack/2012/03/21/what-exactly-isbusiness-development/> [Accessed $12^{\text {th }}$ March 2013].

[30]. Synder, R.,D., 1993. A Computerised System Forecasting Spare Parts Sales: A Case Study. Vol 13, iss7 p83-92[online] Available at: $<$ http://www.emeraldinsight.com/journals.htm?articleid=848726\&show $=$ html $>$ [Accessed $10^{\text {th }}$ February, 2013].

[31]. Shukla, A.,2009) http://www.paggu.com/getting-into-roots/what-is-innovation-why-innovation-is-importan/t/ $>$ [Accessed $12^{\text {th }}$ March 2013].

[32]. Shane, S.,2000. 'Prior Knowledge and the Discovery of Entrepreneurial Opportunities"' Organisation Science, VL.11.n.4. pp44869,[online]Available at:Anglia Ruskin University: $<$ http://orgsci.journal.informs.org/content/11/4/448.abstract $>$ [Accessed 11th February 2013].

[33]. Storey, D., J., 2000. Understanding the Small Business Sector. Thomoson learning, London online read,[online]Available at:< http://www.emeraldinsight.com/journals.htm?issn=1462-6004\&volume=15\&issue=3\&articleid=1740748\&show $=$ html $>$ Accessed $11^{\text {th }}$ February 2013].

[34]. Welvaart, $\quad$ B., $\quad$ W., 2006.Social Economic Profile City of CapeTown $<$.http://www.westerncape.gov.za/text/2007/1/city of cape town se profile optimised.pdf $>$ [Accessed $12^{\text {th }}$ March 2013]. 